\title{
STUDENTS' DIFFICULTIES IN INTERPRETING MESSAGE OF LISTENING COMPREHENSION
}

\author{
Ari Saputra ${ }^{1}$, Lalu Arwan Darmajaya ${ }^{2}$, Rudi Anggara Riantara ${ }^{3}$ \\ Universitas Gunung Rinjani ${ }^{1,3}$, Poltekes Kemenkes Mataram ${ }^{2}$ \\ arisaputra2019@gmail.com
}

\begin{abstract}
This research aimed at finding how does the student's difficulties in interpreting the message of the listening comprehension, and to know the factors causes of students' difficulties in interpreting message of listening comprehension for the eleventh-grade students of Madrasah Aliyah Mardhatillah NW Penakake in the school year 2020/2021. The sample of this research was the Eleventh-Grade students of Madrasah Aliyah Mardhatillah NW Penakak. The number of population was 29 students. This research was using qualitative descriptive. The data was gathered by interview, observation and documentation. The result of this research was the Eleventh-Grade students of Madrasah Aliyah Mardhatillah NW Penakak difficult to interpreted message of listening comprehension. It was based on three factors influencing their listening were listening material, listener factor, and physical environment. Therefore, accents, pronunciation, speed of speech, insufficient of vocabulary, different accents of the speaker, lack of concentration were major problems encountered by the Eleventh-Grade students of Madrasah Aliyah Mardhatillah NW Penakak.
\end{abstract}

Keywords: Students'Difficulties, Listening Comprehension, Interpretation

\section{INTRODUCTION}

English is the most crucial language in this globalization era. The English language consists of four skills here are listening, speaking, reading, and writing. English is a foreign language in Indonesia. However, the learner has an obligation to learn it since it exists in the curriculum of education in Indonesia. Penny Ur (1984: 14) cites in Helgesen and Brown ${ }^{1}$ (2003: 17) states that the apparent is needed of the foreign language learner to perceive and comprehend everything they hear, even though they would not do so in their native language. Listening skill is the most important part of communication. Listening skill is badly needed for successful communication in an interaction. When someone has good listening skills, they are able to exchange information and ideas with others orally. Study shows that people

\footnotetext{
${ }^{1}$ Brown, H. (2000). Principles of Language Learning and Teacbing. San Francisco Fondatia : Jurnal Pendidikan Dasar

Volume 5, Nomor 1, Maret 2021; 44-61 https://ejournal.stitpn.ac.id/index.php/fondatia
} 
spend $80 \%$ of their waking hours communicating, and $45 \%$ of that time is spent on listening (Lawson 2007) ${ }^{2}$.

In the teaching-learning process especially in English foreign class, listening becomes very crucial. Without good listening skills, students have a risk to lose a lot of important information. Listening skill supports the students to get the comprehensible input when they are learning. Students should have a good ability to listen to English words but most students cannot catch them well through listening. Most students cannot identify the grammatical words so they cannot get the points of what speakers say when they are listening.

Good listeners will be able to re-tell what they listen accurately, but many students cannot get the information from what they listen as the result, they cannot re-tell information they listen to others. Using a background of knowledge to predict and later to confirm meaning and recalling important words and ideas are also the aspects in language, but many students have less of a background of knowledge about the English.

On Monday September $14^{\text {th }} 2020$, the researcher did preliminary observation toward the eleventh-grade students of Madrasah Aliyah Mardhatillah NW Penakak. The researcher found out that almost all of the students got minimum score at listening comprehension. Many of them failed to meet at least the minimum standard score because they were unable to listen to the English text well in the class. Besides, the listening class was seldom to be conducted. It was just conducted once or twice a month because this school has no laboratory. It made the students become unfamiliar with the listening itself and also unfamiliar with listening to the English native speaker. Then, the researcher asked for the students to write down the sentences that they heard from the researcher. When they could listen to the sentences, they failed to write what they heard correctly even they wrote another word which were the same sound as the researcher sentences. Finally, the researcher tried to communicate to the students by giving statements and questions using English language but the students got difficult to interpret it. It could be seen from these conversations. The researcher "What will you do to prevent the corona virus spread widely among us?" then the students answered "emmm, yes, corona is dangerous, corona can kill us". The researcher "Oh

${ }^{2}$ Lawson (2007) Talking, Listening, and Learning in Inverclyde: An Evaluation. Invercycled (Scotland). Council, University of Strathclyde. 
really? well, how does covid-19 able to kill us?" then the students answered "you know, from Television, internet". The researcher "could you mention what are the symptoms of people who are being infected by covid-19?" then the students just be quiet.

From the result of preliminary observation above the students could not understand what were the researcher says. When the students tried to comprehend the sentences from the researcher, they misinterpret it. It was because they interpreted the sentences word by word. Furthermore they were lack of practice listening comprehension it made the students heard the sounds of some words were same with another words.

Anadapong $^{3}$ (2011) stated in his research entitle A Study of English Listening Problems and Listening Proficiency of Business at Bangkok. University. The result of the study reveal that the main reason caused listening problem for the students was the listening text. However, the factors that mostly causing listening problems were lack of practicing listening skill and lack of exposure to different kinds of listening materials.

Based on the description above, that was a logical reason for the researcher to investigate the students' difficulties in interpreting the messages of listening comprehension for the eleventh-grade students of Madrasah Aliyab Mardhatillab NW Penakak in the school year 2020/2021

\section{RESEARCH METHODOLOGY}

In this research, the researcher used qualitative research. The process of research involves emerging questions and procedures, collecting data in the participants setting, analyzing the data inductively, building from particulars to general themes, and making interpretations of the meaning of data. The final written report has flexible writing. Bogdan and Biklen ${ }^{4}$ (1982: 230) states that qualitative research is descriptive. The data is collected in the form of words of pictures rather than numbers.

\footnotetext{
${ }^{3}$ Anadapong (2011) A Study of English Listening Problems and Listening Proficiency of Business at Bangkok. University.

${ }^{4}$ Bogdan and Biklen (1982). Qualitative Data Analysis: A Source Book of New Methods. California: Sage.
} 
The researcher used descriptive qualitative in this research due to the researcher wanted to describe clearly, widely, and deeply about the student's difficulties in interpreting the message of listening comprehension.

The location of the research was at Madrasah Aliyah Mardhatillah NW Penakak. The researcher selected Madrasah Aliyah Mardhatillab NW Penakak as the location to get the data because of some problems that researcher had found out from the preliminary observation. The researcher conducted the research on October $9^{\text {th }} 2020$. It took one day to observe. Then, the researcher interviewed to the students and the teacher on October $12^{\text {th }} 2020$.

The subject of this research was the eleventh-grade students of Madrasah Aliyah Mardhatillah NW Penakak in the school year 2020/2021. The researcher selected the eleventh-grade students of Madrasah Aliyah Mardhatillah NW Penakak due to listening comprehension was not emphasize in the tenth-grade students at Madrasah Aliyah Mardhatillah NW Penakak, and also towards the twelfth-grade students, teaching English was focus on national examination matter. Moreover, towards the eleventh-grade students at Madrasab Aliyah Mardhatillah NW Penakak, the students' are emphasized in learning listening skills.

There were 29 populations in the eleventh-grade students at Madrasah Aliyah Mardhatillah NW Penakak. The researcher selected all of the students to be the subject of this research because they were including to the criteria.

There were some criteria that must be had by the person or group to be subject research in qualitative research were; the first, they were the learner of the English language. The second, they were including in the activity that the researcher was being researched. The third, they did not prefer to give information from their own fake information. The fourth, they were having time to be interviewed. Fifth, they were including preliminary unfamiliar with the researcher.

The researcher used two instruments to collect the data; observation, and interview.

\section{Observation}

The researcher came to the class during listening comprehension to know the students' condition, and to find out the factors which were causing some difficulties in learning 
listening comprehension towards the eleventh-grade students at Madrasah Aliyah Mardhatillah NW Penakak. .

2. Interview

The researcher conducted three stages in the interview the students; The first stage, the researcher selected 7 students to be interviewed to know deeply students' difficulties in interpreting the message. The second stage, after selected the students, the researcher asked some questions to the students one by one and recorded their answers. The last stage, the result of the interviews was analyzed by the researcher. After interviewed the students, the researcher interviewed the teacher.

The researcher collected the data from the respondents then analyzed it by using qualitative from Miles and Hurberman ${ }^{5}$ (1984). The data was collected through observation, interviews and documentation about the student's difficulties in interpreting the message of listening comprehension.

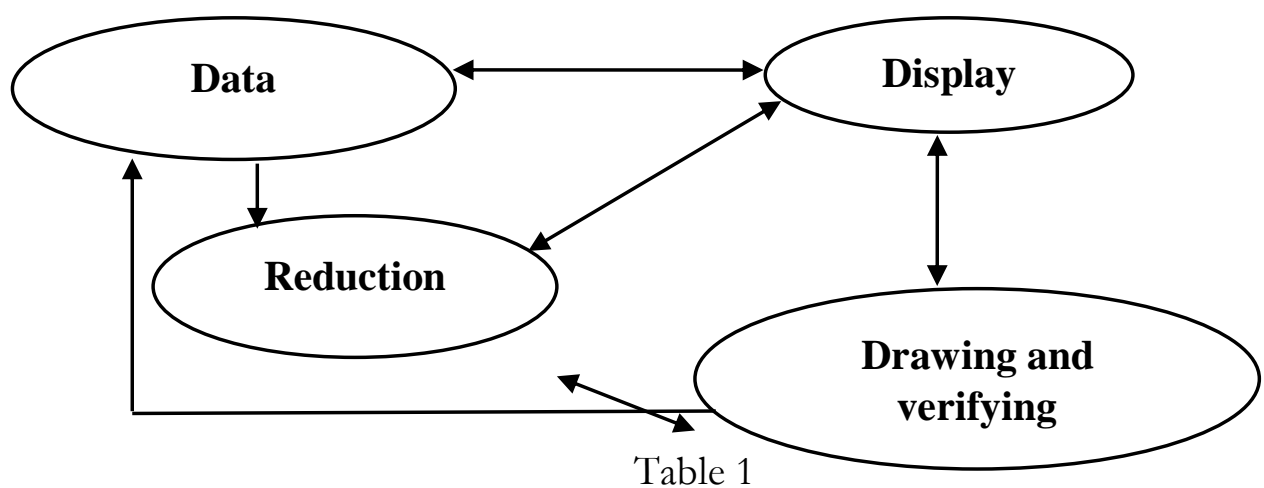

\section{RESULT AND DISCUSSION}

\section{A. RESULT}

The findings of the research based on the results of the data analysis. The data analysis consisted of two sections; the data analysis of interview, and observation. It was held to answer the research question, how does the students' difficulties in interpreted the messages of listening comprehension, and what are the factors causes of students' difficulties in interpreting the message of listening comprehension.

${ }^{5}$ Miles, M.B \& Huberman A.M. (1984). Analisis Data Kualitatif. Terjemahan oleb Tjetjep Rohendi Rohidi. 1992. Jakarta: Penerbit Universitas Indonesia. 


\section{Result of interview}

The researcher had interviewed the students and the teacher on October $12^{\text {th }} 2020$. The researcher displayed the result of interview as follows:

a. The Analysis of the Data Collected from the Result of the Student's Interview

The interview was carried out with 7 volunteer students as discussed in research methodology. These interview due to know deeply about students' difficulties in interpreted the message of listening comprehension. There were five question to know about students difficulties, the first question was: "What were your problems when you interpret the message that you hear in listening comprehension?", the second question was "did you think the material, and the speaker, affect your ability to interpret the message in listening comprehension? Explain!", the third question was "What things that made you difficult to answer the question from the speaker during listening?", the fourth question was "What were the factors made you lost your concentration during listening comprehension?", the last question was "Have you ever used your own personal experience or background knowledge to answer the question in listening? Why?" All of the questions in interview used English but when they were asked for to respond in English, they felt shy, and anxiety. Hence, they were allowed to use Indonesia.

1) Problems Affect Listening Comprehension

First question were asked to know the problems affected the students in interpreted the message of listening comprehension as the listeners. The result showed all of the interviews have various answer, they were:

"Bulenya ngomong terlalu cepat,mmm endah banyak vocab yang sulit yang tidak saya tabu. Itu bikin saya sulit mengartikan yang dia bilang itu.” (interviewee 01)

"Percakapanya panjang kak dan yang dibicarakan itu sulit adek pabami" (interviewee 02) 
"Mmm, marakne ngremon.. hehe. Tapi paham aku dikit-dikit. Gramarnya juga bikin saya bingung dan kurang bisa mengartikan apa yang dibicarakan." (Interviewee 03)

"Aku ndk terlalu bisa di grammar dan yang bicara itu terlalu cepat." (Interviewee 04)

"Aku kurang kosa kata, juga ndk terlalu bisa grammar. Trusan juga," pembicaranya terlalu cepat ngomong." (Interviewee 05)

"Aksenya yang dipakai itu sulit tidak kayak amerika lebib mudab saya pabamnya. Yang bicara itu juga gak. jelas apa yang ucapkan. Yaa,, sebenarnya saya juga kurang vocab sih juga." (Interviewee 06)

"Eeee, yang bikin saya susah menterjemabkanya itu pembicaranya bicara cepat, kan butuh kita waktu untuk berfikir apa artinya kira-kira kata yang ini begitu. Aksenys juga bikin saya bingung british lebih sulit dari amerika..” (Interviewee 07)

"The comments above showed that almost all the students found difficult in interpreting the message of listening comprehension because they were belong to poor knowledge of grammar and lack of vocabulary. The other problems were the length of conversation, speaker spoke too fast, and unclear pronunciation.

2) Problems toward Listening Material and the Speaker

The second questions were asked to know what made them difficult in interpreting the message of listening comprehension regarded to the content of material and the speaker. The students' responded about the difficulties in interpreted the message of listening process as indicated by the following:

"Ya, ada banyak kalimat yang tidak saya pabami, apa yang sedang dibicarakan juga saya tidak paham.” (Interviewee 01)

"Ya kak, pembicaranya sama materinya itu berpengaraub ketika adek coba terjemahin apa maksudnya itu. Kayak materinya terlalu panjang menurut adek.. sama yang ngomong itu kayak gimana ya.... Gak jelas adk dengernya."(Interviewee 02) 
"Ya, menurut saya itu topik yang dibahas itu bikin bingung, gak paham. . Juga dia pakek aksen british makin sulit jadinya."(Interviewee 03)

"Iya, mungkin topik yang dibahas itu asing menurut saya. Trus ada banyak. kosa kata yang coba saya tebak-tebak kira-kira apa artinya begitu itu yang bikin saya bingung dan lama jawab soalnya.” (Interviewee 04)

"Ya, kayaknya begitu. Soalnya kepanjangnya percakapanya. Belum saya selesai terjemabin udah lain yang diomongin. Hilang jadinya, lupak saya arti yang sebelumnya itu.” (Interviewee 05)

"Iya sepertinya begitu, percakapnya itu terlalu panjang trus juga banyak katakata yang baru saya dengar.” (Interviewee 06)

"Ya, soalnya kelamanya bicara lama-lama bingung saya" (Interviewee 07)

The result of the second question showed, all of participants responded that the difficulties in content material were unfamiliar topic and long conversation of listening. There were only two students' said the difficulties in listening material were variety accents and grammar rules of the sentence.

3) Problems to Answer the Question during Listening

The third questions were asked to know the problems encountered by students to answer the question during listeing. There were some good comments given by the students:

"Kurang kosa kataku, trusan ndak q terlalu bisa di grammar itu yang bikin saya kesusahan jawab soal." (Interviewee 01)

"Adek kurang vocab kak, behe. Itu sebenarnya masalabnya adek." (Interviewee 02)

"Salah satu penyebabnya itu saya kadang lupak arti vocabnya jadi saya fokus cari artinya jadinya saya gake fokus dipertanyaan selanjutnya itu yang bikin saya kebingungan.” (Interviewee 03) 
"Gagal fokus,, gake bisa konsen, itu yang bikin saya kesusahan ketika saya cobak artikan yang dibilang itu. Jadi saya gak bisa menjawab soalnya itu."(Interviewee 04)

"Susah jawab soalnya mumgkin karena saya kebingungan denger aksenya itu" (Interviewee 05)

"Ngomongnya terlalu cepat sama aksenya british jadi saya bingung, paham saya sedikit tapi banyakan bingungnya jadinya. Kan kalok kita gak ngerti yang diomngin bagaimana kita bisa jawab soalnya. Ya terpaksa ngarang ngarang saya jawab jadinya." (Interviewee 06)

"Yang bikin saya susah jawab soal itu pas saya tiba-tiba nggak konsen karena memikikirkan jawaban pertanyaan sebelumnya.” (Interviewee 07)

From the results of the third questions of the interview above. It could be drawn that there were some problems of the students during listening. The students could not answer the question from the tapes. Furthermore, the students found difficult to catch the meaning because of lack of vocabulary and poor grammar knowledge, they also lost their concentration because too focused to guess the unknown words. Consequently, they missed what the speaker said in the next question. Therefore they felt panic and made them difficult to answer the question.

4) Problems Lose Concentration during Listening

The fourth questions were asked to know what problems that made the students lose concentration during listening comprehension. The students had various answered as following below:

"Mana bisa kita konsen lasing keributnya sama ada aja teman lain yang minta jawaban sama saya” (Interviewee 01)

"Ketika saya gak paham satu atau dua vocab dari percakapanya jadi konsentrasi saya buyar. Itu sib sebenarnya masalahnyaa" (Interviewee 02)

"Pas ada teman yg ngajak ngomong sama ada teman lain yang bikin ribut."(Interviewee 03) 
"gak bisa konsen saya kalok ribut tusan temen-temen yang laki itu sering minta jawaban..” (Interviewee 04)

"konsenku bilang pas kutulis jawabanya tiba-tiba teman yang lain nanya arti percakapanya." (Interviewee 05)

"Ribut,, trus ndk, bisa diem temen yang lain ada aja yang bikin suara suara. Juga pas ada temen yeng nanya jawaban." (Interviewee 06)

"Kelasnya ribut gak denger apa pertanyaanya itu. Sama temen yang lain mondar mandir enggak bisa diem." (Interviewee 07)

The students' answers showed that average of them said the problem made them lost concentration was the noise in the class. The others problem was if the students could not understand what the speaker said, this interrupts their listening. It means that when the students were failure to concentrate it made the students missed what the speakers said.

5) Problems Used Personal Experience

The fifth questions were asked to know did the students used their own personal experience to interpreted the message of listening comprehension in order to able to answer the questions from the speaker. The students answered as following below:

"Ya itu sering sib saya lakukan pas saya enggak benar-benar paham maksudnya, ya jadi saya kayak ngira-ngira gitu apa artinya jadi saya bisa jawab soalnya" (Interviewee 01)

"Ya kak, saya itu kadang-kadang nebak artinya menurut saya sendiri mungkin aja kan artinya mirip-mirip sama vocab yang saya hafalin.” (Interviewee 02)

"Biasanya begitu,, pas saya gak tau artinya. Ya dari pada bingung saya artikan aja pakek logika saya" (Interviewee 03)

"Ya, saya kayak begitu, saya gak tau musti kayak gimana pas saya enggak tau artinya, saya karang-karang aja artinya." (Interviewee 04) 
"Iya, saya kadang ngerti beberapa vocab aja trus artinya itu saya gabung-gabung. Ya,", akbirnya bisa saya artikan walaupun mungkin enggak benar. Hehe" (Interviewee 05)

"Tya karena susah, saya gak bisa artinya." (Interviewee 06)

"Iya, pas saya bingung enggak tau artinya saya kira-kira artinya apa" (Interviewee 07)

b. The Analysis of the Data Collected from the Result of the Teacher's Interview

1) What were the problems that affect the students in interpreting the message of listening comprehension based on your observation as a teacher?

"Sejauh ini yang saya lihat siswa kami memang kurang vocabulary. Itu adalah pokok masalahnya kenapa mereka mungkin tidak bisa menterjemabkan apapun topik yang mereka dengar. Sehingga mereka kesulitan ketika menjawab soal listening. Ditambah lagi mungkin siswa kami ini kurang praktik listening karena memang kami belum punya laboratorium bahasa inggris. Oleh karena itu praktik listening jarang dilakukan. Inilah yang membuat mereka tidak terbiasa dengan pelafalan dan aksen dari native speaker. Disisi lain juga listening itu kegiatan yang sulit bagi siswa. Ini yang membuat motivasi belajar siswa menjadi rendab" (The teacher)

From the comment above the big the problems that affect the students in interpreted the message of listening comprehension were the students were lack of vocabulary, lack of practice because there was no English laboratory and the students' motivation to learn listening comprehension was still low.

2) Did you think the material, and the speaker affects the students' ability to interpret the message in listening comprehension? Explain please!

"Saya rasa seperti itu dek. Percakapan yang panjang membuat siswa kesulitan dalam menterjemahkan apa yang mereka dengar dalam dialog karena mungkin mereka masih mentranslatenya dengan metode kata per kata. Ditambah lagi memang pelafalan inggris siswa berbeda dengan native speakernya. Oleh karena itu ketika siswa mendengar dialog dari native speaker mereka berfikir yang mereka dengar itu adalab kata yang berbeda. Oleh karenanya siswa sering salah dalam menterjemabkan dialog yang mereka 
dengar. Biasanya ini sering terjadi ketika mereka mendengar aksen british" (The teacher)

Based on the answer of the teacher above, actually the problem appeared from the students itself. The students found difficult to the length of the material, the native speakers' pronunciation, and the speakers' accent affects the students' ability to interpreted the message of listening comprehension.

3) What things that made the students difficult to answer the question from the speaker during listening?

"Saya rasa kurang kosa kata itu tadi sama kurang praktik listening dek." (The teacher)

From the teacher's answer above, it can be concluded that the lack of practice and lack of vocabulary made the students difficult to answer the question from the speaker during listening comprehension.

4) What were factors made the students lost their concentration during listening comprehension?

"Saya rasa factor yang membuat siswa kebilangan konsen itu karena antar siswa sering saya lihat saling tanya arti dari dialog yang mereka dengar. Sehingga itu tadi membuat keributan dalam kelas dan mengganggu konsentrasi mereka." (The teacher)

Based on the teacher's statement above the noise during listening comprehension was the factor made the students lost their concentration. it affected the students to interpreted the message of listening comprehension.

5) Do you think the students use their own personal experience or background knowledge to interpret the message in order to able to answer the question in listening? Why?

"Iya dek itu benar, saya sudah menanyakanya kepada siswa bagaimana mereka menterjemahkan pesan yang mereka dengar itu. Jadi mereka itu sering menggunakan analogi mereka, mereka seperti mengira-ngira apa sebenarnya arti dari sebuab percakapan dan mereka menterjemabkan sendiri didalam kepala mereka berdasrkan pengetahuan terbatas dan pengalaman-pengalaman mereka itu sendiri." (The teacher)

Based on the teacher's statement above the teacher confirmed that the students used their own personal experience or background knowledge to 
interpret the message in order to able to answer the question in listening. They interpreted the sentences word by word and frequently guessing the meaning of a word from their limited understanding ability.

\section{Result of the Observation}

\begin{tabular}{|c|c|c|c|c|c|}
\hline \multirow{2}{*}{ No } & \multirow{2}{*}{ Aspect } & \multirow{2}{*}{ Indicator } & \multicolumn{2}{|c|}{ Condition } & \multirow{2}{*}{ Note } \\
\hline & & & Yes & No & \\
\hline \multirow{4}{*}{1} & \multirow{4}{*}{ 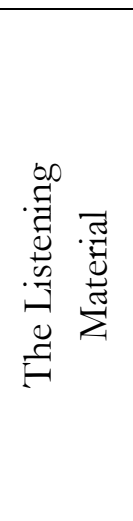 } & $\begin{array}{l}\text { There were many unfamiliar words, } \\
\text { and idioms. }\end{array}$ & & $\checkmark$ & \\
\hline & & $\begin{array}{l}\text { The listening comprehension task had } \\
\text { complex grammatical structure. }\end{array}$ & & $\checkmark$ & \\
\hline & & $\begin{array}{l}\text { The listening comprehension tasks } \\
\text { had unfamiliar topic. }\end{array}$ & $\checkmark$ & & \\
\hline & & $\begin{array}{l}\text { The listening comprehension task had } \\
\text { long conversation. }\end{array}$ & $\checkmark$ & & \\
\hline \multirow{8}{*}{2} & \multirow{8}{*}{ 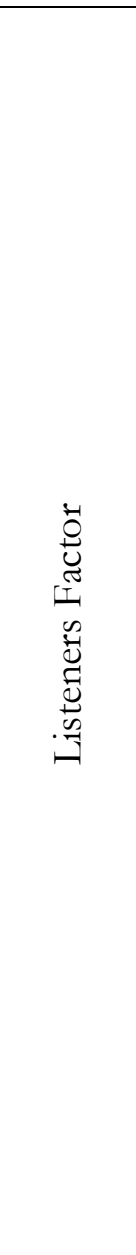 } & $\begin{array}{l}\text { Before doing listening } \\
\text { comprehension tasks, the students } \\
\text { feared that they could not understand } \\
\text { what they hear. }\end{array}$ & $\checkmark$ & & \\
\hline & & $\begin{array}{l}\text { The students were paying attention } \\
\text { while listening }\end{array}$ & $\checkmark$ & & \\
\hline & & $\begin{array}{l}\text { The students were able to } \\
\text { concentrate when searching the } \\
\text { answer and listen at same time }\end{array}$ & & $\checkmark$ & \\
\hline & & $\begin{array}{l}\text { The students did not enthusiasm to } \\
\text { follow the listening comprehension } \\
\text { task }\end{array}$ & $\checkmark$ & & \\
\hline & & $\begin{array}{l}\text { The students could not concentrate } \\
\text { when search the answer and listen at } \\
\text { the same time }\end{array}$ & $\checkmark$ & & \\
\hline & & $\begin{array}{l}\text { The students lost of their } \\
\text { concentration because of limited time } \\
\text { to answer the question }\end{array}$ & $\checkmark$ & & \\
\hline & & $\begin{array}{l}\text { The students felt fatigue and } \\
\text { distracted when they were listening } \\
\text { long spoken texts. }\end{array}$ & $\checkmark$ & & \\
\hline & & $\begin{array}{l}\text { The students used them own } \\
\text { personal experience to answer the }\end{array}$ & $\checkmark$ & & \\
\hline
\end{tabular}




\begin{tabular}{|c|c|c|c|c|c|}
\hline & & question & & & \\
\hline \multirow{5}{*}{3} & \multirow{5}{*}{ 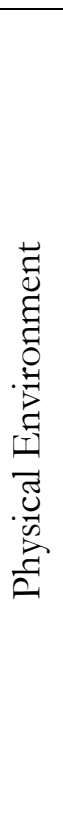 } & $\begin{array}{l}\text { The student found difficult to } \\
\text { understand what the speaker says } \\
\text { because the material was pronounced } \\
\text { unclearly }\end{array}$ & & $\checkmark$ & \\
\hline & & $\begin{array}{l}\text { The students found difficult to } \\
\text { understand when the speaker speaks } \\
\text { too fast. }\end{array}$ & $\checkmark$ & & \\
\hline & & $\begin{array}{l}\text { The students found difficulties } \\
\text { because of the listening test is played } \\
\text { once only. }\end{array}$ & $\checkmark$ & & \\
\hline & & $\begin{array}{l}\text { The students lost their } \\
\text { concentration because the } \\
\text { recorder had poor quality }\end{array}$ & & $\checkmark$ & \\
\hline & & $\begin{array}{l}\text { The students found difficult to } \\
\text { concentrate in the noise atmosphere }\end{array}$ & $\checkmark$ & & \\
\hline
\end{tabular}

The results of table observation above showed that the students found difficult to interpret the message of listening comprehension based on three factors were the listening material, the listener itself and physical environment.

\section{B. Discussions}

This research was aimed for knowing the problems encountered by the eleventh-grade students of Madrasah Aliyah Mardhatillah NW Penakak school year 2020/2021 and providing some suggestion to the teacher to help the students to overcome listening comprehension problems. The observation and interview were used as the instrument in this research. While, the observation sheet was used to confirm students' answered interview. From the explanation above, it could be drawn a conclusion that the students difficult to interpret the message of listening comprehension. It could be seen from the result of interview, and observation during listening. There were some problems from three factors encountering students to interpret the message of listening comprehension. Among these, lack of vocabulary, poor of grammar knowledge, length of spoken text, unfamiliar topic, failure to concentrate, anxiety, lack of interest, variety accents, pronunciation, inability to applied listening strategy, and inability to concentrate.

Lack vocabulary become a main source of the problems because may be the students lack of practice to listen and to read English literature in order to improved 
their grammar and vocabulary. Improving students' vocabulary was not complete without know how to pronounce it, because pronunciation was one of the important things in listening comprehension. Not all problem described above can be overcome. But this did not mean that the teacher could do nothing about them. The teacher needed to provide the students with suitable listening material, background and linguistic knowledge, good motivation, effective listening strategies. There were a few ideas to help the teacher to overcome the student's difficulties in interpreting the message of listening comprehension problems:

1. The teacher must adapted and improved the listening material

Because the student have different knowledge and learning styles so the teacher should build students' interest by giving better material to stimulate and motivate them.

\section{Activating students' vocabulary}

Hamouda $^{6}$ (2013) states that Activating vocabulary by asking them to guess the meaning of word in listening before explaining the meaning to them, since whenever the students were able to relate what they have already known to what they are supposed to listen for, they were likely to listen better and more effectively.

\section{Accents}

Accent is important in listening comprehension. The students' awareness about variety accents from native speaker needed to make them easier to answer question and to interpret the messages in listening comprehension. Give the students' variety accent while practicing listening.

\section{Pronunciation}

The teacher needs to help the students to improve their pronunciation by training from native speaker. It will help them to develop listening acquisition and to train students with accurate pronunciation.

\footnotetext{
${ }^{6}$ Hamouda, Arafat (2013). An Investigation of Listening Comprehension Problems Encountered by Saudi Students in the EL Listening Classroom. International Journal of Academic Research in Progressive Education and Development April 2013
} 


\section{Building students' knowledge about the topic}

The teacher needs to provide the students with different topic that always used in listening comprehension test like TOEFL test. The students have to know the background which is needed to understand the text and it would help them to focus what listen for. It would help them to predict what they hear and make connection to what they already know.

6. Use slow rate of speech

Speaker spoke too fast was one the problem. So train students with slow rate of speech at first. It would help them to know what the speaker said. When the students have understood clearly, try to speed up the rate of audio.

7. Giving some strategy in listening

The one of important thing is giving the students some strategy in listening. It would make the students easier to find the answer of the question from the speaker without think too much and spend their time.

\section{Anxiety}

Motivate students to be positive thinking about their score and support them. The students should do not think too much, just conduct what the students able to conduct.

\section{CONCLUSION}

The purpose of the study were to found out how does the student's difficulties in interpreting the message of the listening comprehension for the eleventh-grade students of Madrasah Aliyah Mardhatillah NW Penakak in the school year 2020/2021?, and to know the factors causing the students' difficulties in interpreting message of listening comprehension for the eleventh-grade students of Madrasah Aliyah Mardhatillab NW Penakak in the school year 2020/2021 during listening comprehension. Based on the data analyzes in chapter IV, It could be concluded that: 
All of the eleventh-grade students of Madrasah Aliyah Mardhatillah NW Penakak in the school year 2020/2021 were difficult to interpret the message of listening comprehension. There were nine problems in students' self learning that were found in analyzing students' difficulties, they were: lack of vocabulary, poor grammar mastery, accent, pronunciation, lack of concentration, speed of speech, anxiety, and noisy. The problems in interpreting the message of listening comprehension faced by students' not only from the listeners themselves but also from content material and environment of listening comprehension. Hence, the students have to study hard and have more practice to improve their listening comprehension.

\section{REFERENCES}

Abidin (2013) English Listening Comprehension Problems of Students from China Learning English in Malaysia.

Ahmadi, Triprasetya, and Joyo. (1997). Strategi Belajar Mengajar (BSM).

Anadapong (2011) A Study of English Listening Problems and Listening Proficiency of Business at Bangkok. University.

Bogdan and Biklen (1982). Qualitative Data Analysis: A Source Book of New Methods. California: Sage.

Brislin, R. W. (1976). Translation: Application and Research. New York: Gardner Press.

Brown, H. (2000). Principles of Language Learning and Teaching. San Francisco:

2001. Teaching by Principles: An Interactive Approach to Language Pedagogy: Second Edition. New York: Longman.

. 2004. Language Assessment: Principles and Classroom Practices. New York: Longman.

Buck, G. (2001). Assessing Listening. Cambridge: Cambridge University Press, www.cambridge.org

Clark, H.H and E.V Clark. (1997). Psychology and Language. London: Harcourt Brace.

Creswell, J. W. 2012. Educational Research . Boston, Canada: Pearson.

Hamouda, Arafat (2013). An Investigation of Listening Comprehension Problems Encountered by Saudi Students in the EL Listening Classroom. International Journal of Academic Research in Progressive Education and Development April 2013

Harmer, Jeremy, 1999. The Practice English Language Teaching. London: Longman. 2007. How to teach English. Pearson Education Limited. 
Helgesen,M and Steven Brown.Practical English languageTeaching Listening.David Nunan,ed.The McGraw-Hill Companies, 2007

Howat, A. and Dakin, J. 1974. "Language Laboratory Materials" Journal ed. J.P.B Allen, S.P.B Allen S.p. Corder.

Lawson (2007) Talking, Listening, and Learning in Inverclyde: An Evaluation. Invercycled (Scotland). Council, University of Strathclyde.

Miles, M.B \& Huberman A.M. (1984). Analisis Data Kualitatif. Terjemahan oleb Tjetjep Rohendi Robidi. 1992. Jakarta: Penerbit Universitas Indonesia.

McCarthy, M. and F. O'Dell. (2010). English Idioms Advanced in Use. Cambridge University Press.

Nunan,D. (2000). Language Teaching Methodology: A Handbook for The Teachers. Cambridge Universitiy Press.

Nurgiyantoro, Burhan. (2002). Teori Pengkajian Fiksi. Yogyakarta: Gadjah Mada University Press.

Penny, Ur. 1999. A course in language teaching, module 16. Cambridge University press Cambridge.

Pramowardhany, E, Nilla. 2003. Mastering and Teaching Listening. Jakarta:

Rost, $M$ (2002) Teaching and Researching Listening, London: Longman.

Tarrigan, Henry Guntur. (2008). Berbicara Sebagai Suatu Keterampilan Berbahasa. Bandung: Angkasa.

Yousif (2006) Listening Comprehension Difficulties as Perceived. 